\title{
Firm's Financial Flexibility: Driving Factors, Flexibility Degree and Economic Results: A Comparison of America and China
}

\author{
Chun-ai Ma ${ }^{1}$, Yanbo Jin ${ }^{2} \&$ Heng-Yu Chang ${ }^{3}$ \\ ${ }^{1}$ China University of Petroleum, Beijing, China \\ ${ }^{2}$ California State University, Northridge, CA, USA \\ ${ }^{3}$ Chang Gung University, Taoyuan, Taiwan \\ Correspondence: Yanbo Jin, College of Business and Economics, California State University, Northridge, 18111 \\ Nordhoff Street, USA. Tel: 1-818-677-4640. E-mail: yanbo.jin@csun.edu
}

Received: August 21, 2015

Accepted: September 14, 2015

Online Published: October 25, 2015

doi:10.5539/ijef.v7n11p52

URL: http://dx.doi.org/10.5539/ijef.v7n11p52

\begin{abstract}
Our paper establishes the causal links among the driving factor, flexibility degree and performance of a firm and tests these links based on two samples made of American and Chinese listed companies in manufacturing industry respectively from 2009 to 2012. Our results show the financial flexibilities of American and Chinese firms are mainly driven by strengthening risk management and chasing investment opportunities respectively, the degree of financial flexibility has positively impact on firm performance, and the effect of financial flexibility driven by chasing investment opportunities on performance is more statistically significant than financial flexibility driven by strengthening risk management. Our results suggest that a firm can improve its performance if it retains a high flexibility degree driven by chasing investment opportunities.
\end{abstract}

Keywords: financial flexibility, flexibility degree, firm performance, risk management, investment opportunity

\section{Introduction}

Financial flexibility represents the ability of a firm to access and restructure its financing at a low cost, financially flexible firms are able to avoid financial distress in the face of negative shocks, and to readily fund investment when profitable opportunities arise (Gamba \& Triantis, 2008). According to this generally accepted definition of financial flexibility, we deduce that strengthening risk management and chasing investment opportunities are two main driving factors for financial flexibility. However, there are some questions about financial flexibility and its driving factors. Whether these two driving factors have similarly strong influences on financial flexibility? Does financial flexibility improve firm performance? Can financial flexibilities play the same role in improving performance when they are driven by different factors? Moreover, in different economic environment, are the results for above questions different? This paper provides empirical evidence to answer these questions.

In this paper, we identify financial flexibility firms by spare debt capacity. following the work of Marchica and Mura (2010), to calculate the predicted level of debt, we develop a leverage equation in which observed leverage is the dependent variable and the significant factors affecting leverage are independent variables, the residual of the estimated model measures the systematic deviation between observed and estimated leverage, we classify a firm as financial flexibility firm if it has negative residual which implies spare debt capacity, our sample is made of financial flexibility firms. Our study focus attention on establishing and testing the causal links among the driving factor, flexibility degree and performance of a firm. In addition, we carry out a comparative study between American and Chinese listed companies in manufacturing industry, and supply some comparative results and analyses for their differences.

First, we econometrically test the factors that drive financial flexibility. Considering financial flexibility is major means of firm's controlling risk and accumulating investment ability, we classify the driving factors into strengthening risk management and chasing investment opportunities. Our empirical results show that firms with higher risks or better growth opportunities have higher degrees of financial flexibility. However, the results for the two samples for "Which is the main driving factor between strengthening risk management and chasing investment opportunities?" are different, in American sample, financial flexibility is mainly driven by 
strengthening risk management, in Chinese sample, chasing investment opportunities is the main driving factor for financial flexibility. In other words, American and Chinese firms' financial flexibility is principally driven by different factors.

Second, we test whether the degree of financial flexibility has positive impact on firm performance. According to existing literature, we predict that firms with higher financial flexibilities can achieve better performances. In both samples, the regression coefficient for firm's financial flexibility are positively correlated with its performance, the results show that financial flexibility can improve firm performance, which is Consistent with the prior research (Marchica \& Mura, 2010; Arslan et al., 2014).

Third, we examine whether financial flexibilities play the same role in improving performance when they are driven by different factors. Financial flexibility driven by strengthening risk management, as a conservative financial policy, means a passive and defensive strategy, and leads to idle resources in financing or cash holding which brings firms the opportunity cost. Empirically, we show that the effect of financial flexibility driven by strengthening risk management on performance isn't statistically significant. By contrast, to seize better investment opportunities, firm retains financial flexibility, this is an active and offensive strategy which can bring abnormal return in the future. Accordingly, the effect of financial flexibility driven by chasing investment opportunities on performance should be more pronounced. Empirically, we show that such effect is statistically significant. Our results indicate that financial flexibility driven by chasing investment opportunities more helps improve firm performance than financial flexibility driven by strengthening risk management, which is consistent with the above analysis.

Finally, we summarize differences between American sample and Chinese sample. They have the similar market competition risks, American firms' sizes are greater than Chinese firms and China is short of some large-scale manufacturing companies. At the same time, the leverage and financial flexibility degree of American firms are higher obviously than Chinese firms. Chinese firms have more investment opportunities and better performance than American firms. American firms' financial flexibilities are mainly driven by strengthening risk management, and their effects on performances are positive but not statistically significant, Chinese firms' financial flexibilities are mainly driven by Chasing investment opportunities, and their effects on performances are positive and statistically significant. We interpret these differences from America and China different developing stages, their firms' different developing desires, and different effects of the global financial crisis of 2008. First, America is a developed country, but China is a developing country whose GDP grows up in over 7\% annually in current twenty years. Second, many American firms have achieved a relatively larger size, and their growths have slowed down. But Chinese firms are smaller and their desires for development and expansion are stronger. At the same time, in Chinese special economic environment, Chinese firms can get more and better development opportunities. Last, the impacts of the financial crisis on China and America are different. Considering that China carried out an important reformation in accounting principles in 2007, we collect data from the 2009 to 2012, empirical results can't avoid the influence from financial crisis.

The paper contributes to the literature on financial flexibility and firm performance. Our paper establishes the causal links among the driving factor, flexibility degree and firm performance, We provide some evidence that firms will obtain the discrepant performance when they retains financial flexibility based on different motives. In the comparison of America and China sample, we find there are some evidently differences in driving factors, flexibility degrees, firm performances and the relationships among them. Our results suggest that one firm will get better performance when it retains high degree of financial flexibility driven by chasing investment opportunities. Our analysis significantly extends the literature on financial flexibility and firm performance.

The remainder of the paper is organized as follows. In Section 2, we explain our hypothesis development. In Section 3, we discuss Sample, data and the empirical methodology used in this paper. In Section4, we present the empirical results and analysis. Finally, we conclude in Section 5.

\section{Hypotheses Development}

\subsection{Driving Factors of Financial Flexibility}

First, Financial flexibility is associated with firm's consideration of controlling risk. For many firms, survivals are the first priority, they have to take some measures against bankruptcy risk, among these measures, financial policies are very important, for example, many researches indicate that firms facing competitive threats usually adopt more conservative financial policies to decrease bankruptcy risk, these conservative financial policies usually insist of adopting low leverage (Sanyal \& Bulan, 2011), holding more cash (Bolton \& Scharfstein, 1990; Haushalter et al., 2007; Fresard, 2010), and so on. Some research further find that risk management and some financial policy are endogenously (Lin \& Paravisini, 2013; Bolton et al., 2011). Conservative financial policies 
can bring financial flexibility which can help them face the unexpected fund's need. After studying the relationship between financial flexibility and risk management, Bonaimé et al. (2013) deem that risk management contributes to financial flexibility.

Second, Financial flexibility is also a result of the strategic decisions made by the firm related to investment and development. In the presence of market frictions, it is difficult for firms to get enough funds at a low cost in a short time when investment opportunities arise, so some firms retains financial flexibility for these anticipated valuable growth options in the future. For these financial flexibility firms, they have enough spare borrowing power to raise external funds for larger capital expenditures in the years following the conservative financial policy (Marchica \& Mura, 2010). Relative researches support this view that firms can sacrifice borrowing today to enhance their ability to seize better growth opportunities in the future (Marchica \& Mura, 2010), and firms with more financial flexibility have higher future investment ability than firms with less financial flexibility (Jong et al., 2012; Denis \& McKeon, 2012; Marchica \& Mura, 2010). Ferrando et al. (2013) go a step further to reveal that an average company that maintains a low leverage policy for at least three years can increase its capital expenditure by around $22.6 \%$.

Collectively, we attribute financial flexibility to firm's consideration of controlling risk and accumulating investment ability, this discussion leads to the first testable hypothesis in our paper.

Hypothesis 1: strengthening risk management and chasing investment opportunities drive a firm keeping financial flexibility.

\subsection{The Relationship between Flexibility Degree and Firm Performance}

Financial flexibility is the ability of a firm to take advantage of unexpected opportunities or to deal with unexpected events at a low cost. Financial flexibility firms can enjoy easier access to external capital markets to meet funding needs arising from unanticipated earnings shortfalls and/or new growth opportunities, and avoid situations that lead to suboptimal investment and poor performance (Arslan et al., 2014). As a result, performances of financially flexible firms should be more stable and better than other firms. Many researchers have proved this judgment, Marchica and Mura (2010) find that financial flexibility companies are not only able to invest more but also seem to invest better, and their long-run performance outperform the market. Arslan et al. (2014) examine the impact of financial flexibility on the investment and performance of East Asian firms over the period 1994-2009, and the results show firms that are financially flexible prior to this crisis perform better than less flexible firms during the crisis.

This discussion leads to our second hypothesis.

Hypothesis 2: the degree of financial flexibility has positively impact on firm performance.

\subsection{The Difference of Effect of Financial Flexibility Driven by Different Factors on Performance}

Any firm feels great pressure when it is in the high risk of bankruptcy, in order to survive it should have to improve the degree of financial flexibility passively, because according to Sayyad and Ulvenäs (2011), financial flexibility is "forward-looking" in that sense that it is related to managers' expectations of the probability of future negative shocks. In such a situation, as a conservative financial policy, financial flexibility means firm's defensive strategy. Retaining high degree of financial flexibility implies idle resources in financing or cash holding, and maybe lead to the opportunity costs. Hence, we deduce the effect of financial flexibility driven by strengthening risk management on performance is weak.

By contrast, to seize better investment opportunities, firms also retain high degrees of financial flexibility when they anticipate some profitable opportunities will arise in the future, this is an active and offensive strategy. Financial flexibility brings firms not only larger capital expenditures, but also better investment (Marchica \& Mura, 2012), and leads to abnormal return finally. Accordingly, we predict that the effect of financial flexibility driven by chasing investment opportunities on performance is strong.

Based on this discussion, we propose the third hypothesis.

Hypothesis 3: financial flexibilities play different role in improving performance when they are driven by different factors. The effect of financial flexibility driven by chasing investment opportunities on performance is stronger than financial flexibility driven by strengthening risk management.

\section{Sample, Data and Methodology}

\subsection{Sample Construction}

Our starting sample comprises listed companies from America and China in manufacturing industry over the 
2009-2012 period. We choose American and Chinese companies because they are in different economic environments, America is a developed country, but China is a developing country and an emerging economy, if data from these two countries can support our hypotheses, we can draw a conclusion that our hypotheses can undergo the test of experiment and the relationships among driving factor, flexibility degree and firm performance are stable. In addition, the comprehensive comparisons between American and Chinese companies maybe bring us some interesting conclusions which are helpful for us to get a clearer understanding of their companies than before.

Considering for following reasons, we focus on the manufacturing industry. First, for both of America and China, manufacturing industry is very important for their economic development. At the same time, due to relatively low barriers to entry, there are so many companies and so fierce competition in this industry, This allows us to have a large sample size for statistical testing; the variability of competition allows us to design specific risk variables for testing as well.

The key factor influencing our data period is Chinese reform in Accounting Standards in 2007, Chinese new Accounting Standards came into effect in this year, the reform has material effect on the Chinese companies' data from financial statements, information provided by the same firm loses comparability before and after 2007 . To avoid the impact of this abnormal event on empirical results, we use the date from 2009 to 2012.

We identify the initial sample which is made of all manufacturing companies according to American standard industry classification code and Chinese securities regulatory commission industry Code. Subsequently, we calculate these companies' spare debt capacity according to Frank and Goyal's (2009) baseline mode. Last, we identify firms with spare debt capacity as financial flexibility firms and consider them as our final sample. The final sample consists of 8683 firm-year observations which are made of 7207 American observations (1803, 1804, 1801, 1799, from 2009 to 2012, respectively ) and 1476 Chinese observations s(336, 404, 400, 336, from 2009 to 2012 , respectively).

\subsection{Regression Variables and Descriptive Statistics}

\subsubsection{Measuring Risk}

For any firm, there are so many risks which can bring threat to its survival, among them, product market risk is chosen as subject investigated in this paper, because in an open market, the fierce competition between the rival products is very common, the threat from product market is an important and daily operating risk which can't be ignored by any firm. The degree of product market risk depends on the level of market concentration, and the most common measure of market concentration has historically been the Herfindahl-Hirschman Index (HHI), which is defined as:

$$
H H I=\sum_{i=1}^{n} s i^{2}
$$

where $n$ is the number of firm and $S_{i}$ is the market share of firm $i$.

The greater the HHI is, the lower the product market risk is.

\subsubsection{Measuring Investment Opportunities}

Tobin's q is perhaps the most commonly used proxy for investment opportunities, which is a ratio that relates the market value of a firm to the replacement cost of its assets. The extent to which the former exceeds the latter indicates the firm's future investment opportunities. In empirical applications, the book value of a firm's assets often serves as a proxy for the replacement cost of capital.

\subsubsection{Measuring the Degree of Financial Flexibility}

Some researchers find spare debt capacity is the primary source of financial flexibility for many firms (Daniel, Denis, \& Naveen, 2012), and conservative leverage can improve a firm's financial flexibility (Marchica \& Mura, 2010), so Marchica and Mura (2010) proposed measuring the degree of financial flexibility based on systematic deviations between observed and estimated leverage. We support this attempt, and estimate the deviations based on Frank and Goyal's (2009) baseline model. First, among many definitions of leverage, we chose the ratio of total debt to market value of assets (TDM) because it is a market-based definition of leverage. Subsequently, we calculate the six core factors in Frank and Goyal's model, which consist of industry median leverage, tangibility, profits, firm size, market-to-book assets ratio and expected inflation, methods of calculation for them are same to Frank and Goyal's (2009). Then, we can get systematic deviations between observed and estimated leverage 
based on following fixed-effects model, which controls for firm- and time-specific effects:

$$
\begin{array}{r}
\text { LEVi } t=\alpha_{0}+\beta_{1} \text { industry median leverage it }+\beta_{2} \text { tangibility it }+\beta_{3} \text { profitsit }+\beta_{4} \text { firm sizeit }+\beta_{5} \text { market-to-book } \\
\text { assets ratio it }+\beta_{6} \text { expected inflation it }+\varepsilon_{i t} .
\end{array}
$$

Last, we classify the firms with negative deviations as the financial flexibility firms, their degrees of financial flexibility are the absolute values of negative deviations, the greater this absolute value is, the higher firm's financial flexibility degree is.

\subsubsection{Measuring Firm Performance}

To avoiding to the effects of nonoperational factors such as leverage and taxes, and following Brav et al. (2008), we use return on assets (ROA, defined as the ratio of EBITDA to lagged assets) and operating profit margins (OPM, defined as EBITDA/sales) as measures of operating profitability. Among them, OPM is used in the test of the robustness of our results.

\subsubsection{Other Control Variables}

Firm's size and leverage have been widely recognized to affect financial flexibility (Ang \& Smedema, 2011) and performance (Karaca \& Eksi, 2012; Isik \& Soykan, 2013), hence they are included in the theoretical model as control variables. Firm size was measured by the logarithm of the firm's total assets, and leverage was measured by the ratio of total debt divided by total assets.

All variables used in this study and their definitions can be referred from table1.

Table 1. Description and symbol of variables used in this study

\begin{tabular}{llc}
\hline Variables & Description & Symbol \\
\hline Product Market Risk & Herfindahl-Hirschman Index & HHI \\
Investment opportunities & Tobin's Q: Market value of equity plus total debt to total assets & T Q \\
Return on assets & EBITDA to lagged assets & ROA \\
Operating profit margins & EBITDA to sales & OPM \\
Size & Natural logarithm of total assets & SIZE \\
Leverage & Debt to total assets. & LEV \\
\hline
\end{tabular}

\subsubsection{Descriptive Statistics}

Table 2 reports summary statistics for the variables used in our multivariate regression models. At the same time, the independent samples t-test is used for comparing the difference of all variables between America and China, The results show there are significant differences for these variables except HHI.

First, the difference of American HHI and Chinese HHI is not significant, which indicates American market competition risk in manufacturing industry is similar to Chinese. Due to relatively low barriers to entry, the manufacturing companies in both of America and China have to face fierce market competition.

Second, American and Chinese TQ medians and mean are 1.342, 1.771 and 2.346, 2.867 respectively, Chinese firms have more growth and investment opportunities. For many American companies, they have achieved a relatively larger scale, and their growths have slowed down. On the other hand, as a country whose GDP grows up in over $7 \%$ annually in current twenty years, China is called emerging economy, in Chinese special economic environment, Chinese companies can get more growth and investment opportunities, at the same time, the scales of Chinese companies are relatively small, they have strong desires for development and expansion.

Third, the median and mean of American firms' financial flexibility degree are 0.555 and 0.573 , which are far above Chinese firms' 0.065 and 0.081 , so the flexibility degree of American firms is higher obviously. We considerate this result is relative to the differences of financial crisis's impacts on economy between America and China. Because of Chinese accounting principles reformation in 2007, we collect data from 2009 to 2012. As a result, our empirical results have to be impacted by the financial crisis more or less. America suffers a more serious defeat than China from the crisis, American companies have to pay more attention to controlling risks and recovering economy, which causes American companies to retain an abnormally high degree of financial flexibility.

Subsequently, the performance of American firms is far lower than Chinese firms based on not only ROA, but also OPM. To develop market economy, Chinese government always pays more attention to the development of manufacturing industry and companies. Because of the rapid development of manufacturing industry, even 
China is regarded as world manufacture center once. Chinese government carries out many preferential policies in financing, tax and market access in order to support manufacturing firms' development, which help improve the profit-making abilities of firms.

Last, from the first control variable (size), we can find American firms' sizes are greater than Chinese firms and China is short of some large-scale manufacturing companies. We can attribute it to the difference of economic development, America is a developed country, it has cultivated a large number of large-scale manufacturing companies in a long-term development, such as Ford Motor and Procter \& Gamble, both of them are big companies with over 100 years history. But by comparison, Chinese market economy is put on the agenda in1978, and now China is still in the period of constructing market economy, China need more time to cultivate her large-scale companies. Another control variable (leverage) indicates American firms' leverages are higher and firms in America can make full use of debt to get more funds, this difference should be related to the development of capital market, American capital market is mature market and can provide more debt financing instruments which help companies raise capital from many sources. Chinese capital market is not yet matured and only supply some limited debt financing instruments to firms.

Table 2. Summary statistics of model variables for the pooled samples

\begin{tabular}{|c|c|c|c|c|c|c|c|c|}
\hline \multirow{2}{*}{ Variable } & \multicolumn{4}{|c|}{ America } & \multicolumn{4}{|c|}{ China } \\
\hline & Obs & Median & Mean & StDev & Obs & Median & Mean & StDev \\
\hline HHI & 7207 & 0.041 & 0.056 & 0.055 & 1476 & 0.041 & 0.060 & 0.040 \\
\hline TQ & 7207 & 1.342 & 1.771 & 1.567 & 1476 & 2.346 & 2.867 & 1.746 \\
\hline $\mathrm{FF}$ & 7207 & 0.555 & 0.573 & 0.215 & 1476 & 0.065 & 0.081 & 0.070 \\
\hline ROA & 7207 & 0.104 & 0.057 & 0.324 & 1476 & 0.107 & 0.132 & 0.158 \\
\hline OPM & 7207 & 0.100 & -0.503 & 4.440 & 1476 & 0.140 & 0.248 & 0.479 \\
\hline SIZE & 7207 & 27.642 & 27.939 & 5.543 & 1476 & 21.907 & 22.120 & 1.176 \\
\hline LEV & 7207 & 0.571 & 0.568 & 0.216 & 1476 & 0.404 & 0.406 & 0.169 \\
\hline
\end{tabular}

\subsection{Methodology}

To test the driving factors of financial flexibility in hypothesis 1, we estimate the following fixed-effects model, which controls for firm- and time-specific effects:

$$
F F_{i t}=\alpha_{0}+\beta_{1} H H I_{i t}+\beta_{2} T Q_{i t}+\beta_{3} \operatorname{SIZE}_{i t}+\beta_{4} L E V_{i t}+\varepsilon_{i t}
$$

To test the relationships between financial flexibility's degree and firm performance (hypothesis 2 ) and the difference of effect of financial flexibility driven by different factors on performance (hypothesis 3 ), we estimate the following fixed-effects model, which also controls for firm- and time-specific effects:

$$
R O A_{i t}=\alpha_{0}+\beta_{1} F F_{i t}+\beta_{2} S I Z E_{i t}+\beta_{3} L E V_{i t}+\varepsilon_{i t}
$$

\section{Results and Analysis}

\subsection{The Result of Regression}

From equation 3, we get the regression results for the driving factors of financial flexibility (H1) which is reported in Table 3. The regression results according to equation 4 is reported in following table 4, which includes the regression results for the relationship between financial flexibility's degree and firm performance $(\mathrm{H} 2)$ as well as the difference of effect of financial flexibility driven by different factors on performance $(\mathrm{H} 3)$.

\subsubsection{The Driving Factors of Financial Flexibility (Hypothesis 1)}

Table 3 reports the regression results for H1's prediction that strengthening risk management and chasing investment opportunities drive a firm keeping financial flexibility. In line with this prediction, the regression coefficients for firm's risk (proxied by HHI) and investment opportunities (proxied by TQ) are negatively and positively correlated with financial flexibility(proxied by FF) respectively, which indicate that higher product market risk and better investment opportunities can drive a firm's higher financial flexibility.

Of product market risk and growth opportunity, which is the main driving factor? The results are different, in American sample, the regression coefficient for a firm's product market risk is significantly correlated with financial flexibility, but in Chinese sample, the significant regression coefficient is for investment opportunities. So we can draw a conclusion that American and Chinese firms' financial flexibilities are mainly driven by strengthening risk management and chasing investment opportunities respectively. Further, we classify them into 
two types, American firms are the sample driven by strengthening risk management, and Chinese firms are the sample driven by chasing investment opportunities.

Table 3. Results of estimating the relationships among risk, investment opportunities and financial flexibility

\begin{tabular}{lcccc}
\hline & \multicolumn{2}{c}{ America } & \multicolumn{2}{c}{ China } \\
\cline { 2 - 5 } & Estimate & P-value & -0.032 & P-value \\
\hline HHI & $-0.104^{* * *}$ & 0.007 & $0.010^{* * *}$ & 0.444 \\
TQ & 0.002 & 0.179 & $0.052^{* * * *}$ & 0.000 \\
SIZE & $0.045^{* * *}$ & 0.000 & $-0.183^{* * *}$ & 0.000 \\
LEV & $-0.540^{* * *}$ & 0.000 & $-1.013^{* * *}$ & 0.000 \\
Constant & $-0.365^{* * *}$ & 0.000 & $y e s$ & 0.000 \\
\hline Firm Fixed effect & $y e s$ & & $y e s$ & \\
Year Fixed effect & $y e s$ & & 0.539 & \\
$R$-Square & 0.699 & & 1476 & \\
Observations & 7207 & & & \\
\hline
\end{tabular}

Note. $* * *$ indicates that the coefficient is significant at the $1 \%$ level.

\subsubsection{The Relationship between Flexibility Degree and Firm Performance (Hypothesis 2)}

Our regression results relating to $\mathrm{H} 2$ that the degree of financial flexibility (proxied by FF) has positively impact on firm performance (proxied by ROA) are reported in table 4. In both of two samples, the regression coefficients for firms' financial flexibilities are positively correlated with their performances, which support our prediction in $\mathrm{H} 2$. However, the effect is only statistically significant among the Chinese firms.

Table 4. Results of estimating the relationship between flexibility degree and firm performance (ROA)

\begin{tabular}{|c|c|c|c|c|}
\hline & \multicolumn{2}{|c|}{ America } & \multicolumn{2}{|c|}{ China } \\
\hline & Estimate & $P$-value & Estimate & $P$-value \\
\hline FF & 0.057 & 0.262 & $0.246^{* * *}$ & 0.016 \\
\hline SIZE & 0.001 & 0.895 & -0.002 & 0.797 \\
\hline LEV & 0.022 & 0.691 & $-0.091^{* *}$ & 0.043 \\
\hline Constant & -0.016 & 0.937 & 0.192 & 0.202 \\
\hline Firm Fixed effect & yes & & yes & \\
\hline Year Fixed effect & yes & & yes & \\
\hline$R$-Square & 0.010 & & 0.084 & \\
\hline Observations & 7207 & & 1476 & \\
\hline
\end{tabular}

Note. $* *$ indicates that the coefficient is significant at the $5 \%$ level.

4.1.3 The Difference of Effect of Financial Flexibility Driven by Different Factors on Performance (Hypothesis 3)

In $\mathrm{H} 3$, we predict that financial flexibilities play different role in improving performance when they are driven by different factors. The effect of financial flexibility driven by chasing investment opportunities on performance is stronger than financial flexibility driven by strengthening risk management. According to regression results in table 4, in American sample which is classified as the group driven by strengthening risk management, the regression coefficient shows the effect of a firm's financial flexibility on its performance is not statistically significant. On the contrary, in Chinese sample classified the group whose financial flexibility is driven by chasing investment opportunities, this regression coefficient is significant. Hence, financial flexibility driven by chasing investment opportunities can more help improve firm performance than financial flexibility driven by strengthening risk management, $\mathrm{H} 3$ is proved.

\subsection{Robustness Checks}

To test the robustness of our result, we substitute OPM for ROA in measuring firm performance and repeat the estimation of equation 4. The regression results are reported in Table 5. Consistent with our previous findings, the degree of financial flexibility has positively impact on firm performance, financial flexibilities play different 
role in improving performance when they are driven by different factors. The financial flexibility driven by chasing investment opportunities more helps improve firm performance than financial flexibility driven by strengthening risk management.

Table 5. Results of robustness checks (results of estimating the relationship between the flexibility degree and firm performance (OPM))

\begin{tabular}{|c|c|c|c|c|}
\hline & \multicolumn{2}{|c|}{ America } & \multicolumn{2}{|c|}{ China } \\
\hline & Estimate & $P$-value & Estimate & P-value \\
\hline $\mathrm{FF}$ & 0.353 & 0.535 & $0.535^{*}$ & 0.090 \\
\hline SIZE & $0.173^{* *}$ & 0.038 & 0.035 & 0.144 \\
\hline LEV & $1.614 * * *$ & 0.009 & -0.135 & 0.346 \\
\hline Constant & -6.466 & 0.004 & -0.520 & 0.275 \\
\hline Firm Fixed effect & yes & & yes & \\
\hline Year Fixed effect & yes & & yes & \\
\hline$R$-Square & 0.030 & & 0.017 & \\
\hline Observations & 7207 & & 1476 & \\
\hline
\end{tabular}

Note. *,**, and *** indicate that the coefficient is significant at the $10 \%, 5 \%$ and $1 \%$ level, respectively.

\subsection{A Comparison between America and China}

Due to suffering different impact in financial crisis and being in different economic environment, although both of American and Chinese firms face similar market competition risk in manufacturing industry, Chinese firms can get more investment opportunities.

American firms' financial flexibilities are mainly driven by strengthening risk management and retain higher degree as a whole, but as a conservative financial policy to decrease bankruptcy risk, high financial flexibility maybe leads to idle resources and opportunity cost, so that it can't improve firms' performance significantly. In other words, a defensive strategy directing to financial flexibility usually means potential economic losses for the firms.

Chinese firms' financial flexibilities are mainly driven by chasing investment opportunities, financial flexibility helps firms seize more investment opportunities, and bring larger capital expenditures or better investment, so they can improve firm performance significantly finally. The result indicates that an active and offensive strategy directing to financial flexibility is necessary for firms if they expect to obtain a better economic performances.

\section{Conclusion}

Financial flexibility has become a popular research topic in recent years (Jong, Verbeek, \& Verwijmeren, 2012). To answer the following quesrions, what drives a firm's financial flexibility? Does financial flexibility improve firm performance? Can financial flexibilities play the same role in improving performance when they are driven by different factors? In different economic environment, are the answers to above questions different? We study the relationships among the driving factor, flexibility degree and firm performance, and make a contrast based on two samples made of American and Chinese listed companies in manufacturing industry.

Our main results show that strengthening risk management and chasing investment opportunities can drive a firm's higher financial flexibility, the degree of financial flexibility has positively impact on firm performance, and the effect of financial flexibility driven by chasing investment opportunities on performance is more statistically significant than financial flexibility driven by strengthening risk management, all our hypotheses are supported.

The contrast between American and Chinese sample implies they have the similar market competition risk in manufacturing industry. American firms' sizes are greater than Chinese firms and China is short of some large-scale manufacturing companies, at the same time, the leverage and financial flexibility degree of American firms are higher obviously than Chinese firms. Chinese firms have more investment opportunities and better performances than American firms. Additionally, the results of empirical test shows American and Chinese firms' financial flexibilities are mainly driven by strengthening risk management and chasing investment opportunities respectively. In American sample, the effect of firm's financial flexibility on performance is not statistically significant. On the contrary, in Chinese sample, the effect is significant. We provide the explanations for these differences mainly from America and China different developing stages, their firms' different developing desires, 
and different effects of the global financial crisis in 2008.

Overall, our paper establishes and tests the causal links among the driving factor, flexibility degree and firm performance, Our analyses significantly not only extend the literature on financial flexibility and firm performance, but also give firms a practical suggestion that one firm will get better performance when it retains high degree of financial flexibility driven by chasing investment opportunities.

\section{Acknowledgments}

This paper is one part of the research project "the influence path of financial flexibility on corporate value (project number: 71202118)," which is supported by the National Natural Science Foundation of China, as well as the research project "the research on financial flexibility from the perspective of risk management (project number: ZX20150132)" Supported by Science Foundation for the Excellent Youth Scholars in China University of Petroleum, Beijing.

\section{References}

Ang, J., \& Smedema, A. (2011). Financial Flexibility: Do Firms Prepare for Recession? Journal of Corporate Finance, 17(3), 774-787. http://dx.doi.org/10.1016/j.jcorpfin.2011.02.001

Arslan, Ö., Florackis, C., \& Ozkan, A. (2014). Financial Flexibility, Corporate Investment and Performance: Evidence from Financial Crises. Review of Quantitative Finance and Accounting, 42(2), 211-250. http://dx.doi.org/10.1007/s11156-012-0340-x

Bolton, P., \& Scharfstein, D. S. (1990). A Theory of Predation Based on Agency Problems in Financial Contracting. The American Economic Review, 80(1), 93-106.

Bolton, P., Chen, H., \& Wang, N. (2011). A unified Theory of Tobin's q, Corporate Investment, Financing, and Risk Management. Journal of Finance, 66(5), 1545-1578. http://dx.doi.org/10.1111/j.1540-6261.2011.01681.x

Bonaimé, A. A., Hankins, K. W., \& Harford, J. (2013). Financial Flexibility, Risk Management, and Payout Choice. The Review of Financial Studies, 31, 1-28. http://dx.doi.org/10.1093/rfs/hht045

Brav, A., Jiang, W., Partnoy, F., \& Thomas, R. (2008). Hedge Fund Activism, Corporate Governance, and Firm Performance. Journal of Finance, 63(3), 1729-1775. http://dx.doi.org/10.1111/j.1540-6261.2008.01373.x

Daniel, D., Denis, D. J., \& Naveen, L. (2012). Sources of Financial Flexibility: Evidence from Cash Flow Shortfalls. Drexel University, Philadelphia, USA.

Denis, D. J., \& McKeon, S. B. (2012). Debt Financing and Financial Flexibility: Evidence from Proactive Leverage Increases. The Review of Financial Studies, 25(6), 1897-1929. http://dx.doi.org/10.1093/rfs/hhs005

Ferrando, A., Marchica, M. T., \& Mura, R. (2013). Financial Flexibility Across the Euro Area and the UK. European Central Bank, Frankfurt, Germany.

Frank, M. Z., \& Goyal, V. K. (2009). Capital Structure Decisions: Which Factors Are Reliably Important? Financial Management, 38(1), 1-37. http://dx.doi.org/10.1111/j.1755-053X.2009.01026.x

Fresard, L. (2010). Financial Strength and Product Market Behavior: The Real Effects of Corporate Cash Holdings. Journal of Finance, 65(3), 1097-1122. http://dx.doi.org//10.1111/j.1540-6261.2010.01562.x

Gamba, A., \& Triantis, A. J. (2008). The Value of Financial Flexibility. Journal of Finance, 63(5), 2263-2296. http://dx.doi.org/ 10.1111/j.1540-6261.2008.01397.x

Haushalter, D., Sandy, K., \& William, F. M. (2007). The Influence of Product Market Dynamics on a Firm's Cash Holdings and Hedging Behavior. Journal of Financial Economics, 84(3), 797-825. http://dx.doi.org/10.1016/j.jfineco.2006.05.007

Isik, O., \& Soykan, M. E. (2013). Large Shareholders and Firm Performance: Evidence From Turkey. European Scientific Journal, 9(25), 23-37.

Jong, A. D.,Verbeek, M., \& Verwijmeren, P. (2012). Does Financial Flexibility Reduce Investment Distortions? Journal of Financial Research, 35(2), 243-259. http://dx.doi.org/ 10.1111/j.1475-6803.2012.01316.x

Karaca, S. S., \& Eksi, I. H. (2011). The Relationship between Ownership Structure and Firm Performance: An Empirical Analysis over Istanbul Stock Exchange (ISE) Listed Companies. International Business Research, 5(1), 172-181. http://dx.doi.org/10.5539/ibr.v5n1p172 
Lin, H., \& Paravisini, D. (2012). The Effect of Financing Constraints on Risk. Review of Finance, 17(1), 229-259. http://dx.doi.org/10.1093/rof/rfr038

Marchica, M., \& Mura, R. (2010). Financial Flexibility, Investment Ability, and Firm Value: Evidence from Firms with Spare Debt Capacity. Financial Management, 39(4), 1339-1365. http://dx.doi.org/10.1111/j.1755 -053X.2010.01115.x

Sanyal, P., \& Bulan, L. T. (2011). Regulatory Risk, Market Uncertainties, and Firm Financing Choices: Evidence from U.S. Electricity Market Restructuring. The Quarterly Review of Economics and Finance, 51(3), 248-268. http://dx.doi.org/10.1016/j.qref.2011.01.006

Sayyad, K. P., \& Ulvenäs, J. A. (2012). Examining the Sources of Financial Flexibility--A Study of Firms Listed in Sweden. Lund University, Lund, Sweden.

\section{Copyrights}

Copyright for this article is retained by the author(s), with first publication rights granted to the journal.

This is an open-access article distributed under the terms and conditions of the Creative Commons Attribution license (http://creativecommons.org/licenses/by/3.0/). 